\title{
ПРИНЦИП СОЦИАЛЬНОЙ СПРАВЕДЛИВОСТИ И ЕГО РЕАЛИЗАЦИЯ ПОСРЕДСТВОМ СИСТЕМ ВИДЕОКОНФЕРЕНЦ-СВЯЗИ
}

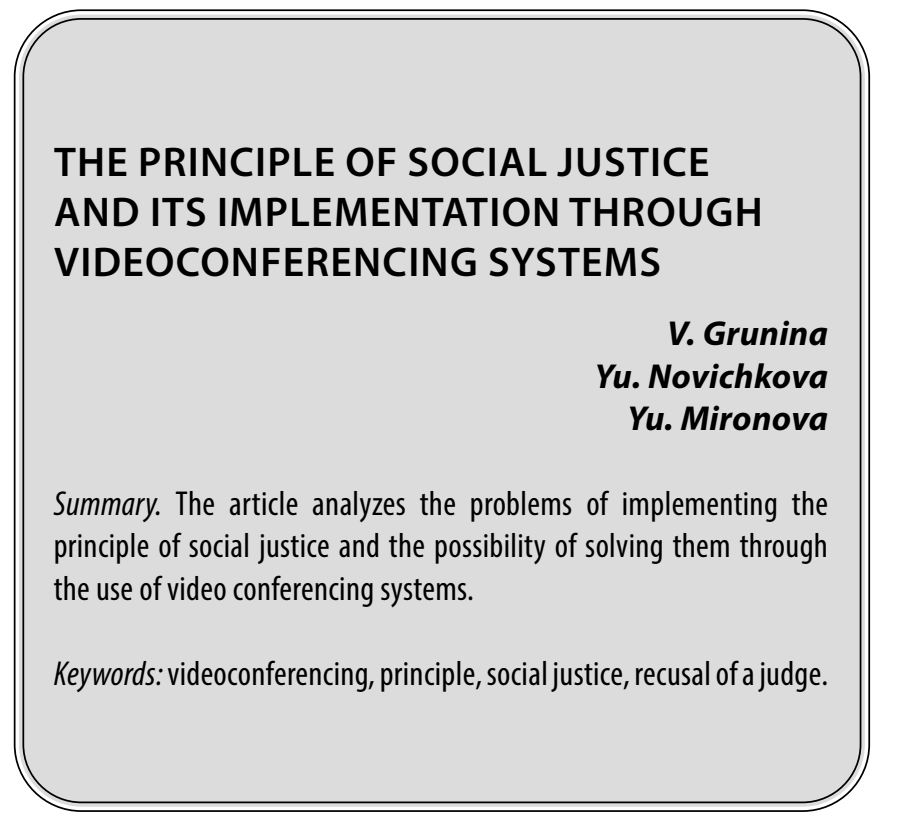

B гражданском процессуальном праве принцип социальной справедливости можно легко спутать с принципом справедливого разбирательства дела, а также с принципом правового равенства [1]. Однако, на наш взгляд, данный принцип следует трактовать более расширенно.

Так, согласно позиции В.А. Вайпана, принцип социальной справедливости, выражается в (а) генетическом, (б) нормативном и (в) функциональном требованиях: а) юридическая норма должна быть адекватным (более или менее) идеально-нормативным слепком лежащего в ее основе материального, экономического, социально-справедливого фактического отношения; б) нормы права должны обеспечивать равенство правовых возможностей для всех субъектов; в) реализация законодательства должна быть абсолютной, соответствовать смыслу и букве правовых предписаний, а поведение адресатов норм должно быть адекватно заложенным в этих нормах моделям поведения [2].

В судебной практике категория справедливости используется в различных значениях: в качестве отдельного принципа, требования или критерия справедливости; оценки обстоятельств дела («справедливый баланс интересов», «справедливое распределение активов», «справедливая цена») или размера компенсации; показателя отношения к судье («справедливость
Грунина Вероника Александровна

К.ю.н., дочент, Владимирский филиал Российской академии народного хозяйства и государственной службы при Президенте Российской Федерации vgrunvgrun@rambler.ru

Новичкова Юлия Геннадьевна Старший преподаватель, Университет ФСИН России (Санкт-Петербург) 3590568@mail.ru

Миронова Юлия Владимировна

Стариий преподаватель, ВЮИ ФСИН России Juliamironova07@mail.ru

Аннотация. В статье анализируются проблемы реализации принципа социальной справедливости и возможности их решения посредством использования систем видеоконференц-связи.

Ключевые слова: видеоконференц-связь, принцип, социальная справедливость, отвод судьи.

судьи»); оценки состояния судебного разбирательства («справедливое рассмотрение дела») или судебного решения; права на справедливое судебное разбирательство и т.д. При этом в большей степени акцент в судебных актах делается на принцип справедливости или справедливое судебное разбирательство [3].

Вместе с тем, зачастую упускается из виду, что понятие справедливости в юридическом смысле является оценочной правовой категорией. Поэтому индивидуальный вывод о справедливости или несправедливости правоотношений должен сделать судья или иной субъект, рассматривающий спор или дело. Это влечет за собой расширение сферы судейского и административного усмотрения, что в условиях российской правовой действительности с неизбежностью порождает ошибки, произвол, отрицательно влияет на экономическое развитие. В итоге стремление обеспечить справедливость в правоприменении с помощью ориентации на высокие идеалы может привести к еще большей несправедливости [3].

Так, с точки зрения применения систем ВКС в процессе организации судебного разбирательства примером обеспечения принципа социальной справедливости может служить вопрос о наличии у суда технической возможности ее организации, а также дифференциации оснований отказа в ее применении. 
Здесь крайне важным вопросом правового регулирования использования ВКС является то, что зачастую суды в вопросе предоставления возможности сторонам участвовать в судебном заседании с применением систем ВКС склоняются к тому, что принятие положительного решения - это право, а не обязанность суда. При этом в любом процессуальном законе отсутствует перечень оснований для отказа суда в удовлетворении ходатайства лица о ВКС. Например, традиционно суды в рамках гражданского судопроизводства отталкиваются от двух оснований: 1) отсутствие технической возможности для участия в судебном заседании с использованием систем видеоконференц-связи; 2) осуществление разбирательства дела в закрытом судебном заседании [4] (ч. 6 ст. 10 ГПК РФ); 3) невозможность проведения заседания по делу в рабочее время в данном суде с учетом разных часовых поясов проживания участников процесса и их территориальной удаленности, а также количеством рассматриваемых дел [5].

Здесь следует указать, что ранее, когда суды общей юрисдикции в общей массе не были оборудованы системами ВКС, отказ суда в связи с отсутствием необходимого технического оборудования в суде был вполне закономерен. Однако, с процессом технического усовершенствования судебной системы, отказ суда в организации ВКС по техническим причинам вызывает много вопросов.

Следует отметить, что в теории гражданского процессуального права термин «техническая возможность» не конкретизирован до сих пор, что существенно затрудняет реализацию не только принципа социальной справедливости, но и негативно сказывается на реализации нескольких межотраслевых основ: принципов состязательности, доступности правосудия, а также равенства граждан перед законом и судом.

При наличии пробела в гражданском процессуальном законодательстве, правоведы руководствуются в этом вопросе п. 24 Постановления Пленума ВАС РФ 17 февраля 2011 г. № 12 «О некоторых вопросах применения Арбитражного процессуального кодекса Российской Федерации в редакции Федерального закона от 27.07.2010 № 228-Ф3 «О внесении изменений в Арбитражный процессуальный кодекс Российской Федерации», в котором под технической возможностью понимается наличие в арбитражном суде исправной системы видеоконференц-связи и объективной возможности проведения судебного заседания данным способом в пределах установленного законом срока рассмотрения дела.

Как мы видим из представленной формулировки, она отнюдь не способствует уточнению и конкретиза- ции вопроса оснований определения наличия технической возможности суда организовать судебное заседание посредством ВКС.

Предложенное Пленумом ВАС РФ толкование включает как технические (наличие системы видеоконференц-связи в конкретном суде и ее исправность), так и организационные (возможность использования этой системы в определенный временной промежуток, ограниченный процессуальным сроком рассмотрения дела) аспекты.

Таким образом, суд, указывая на отсутствие технической возможности при рассмотрении дела с использованием ВКС, никаких объяснений о причинах отсутствия такой возможности не дает. Что касается заявителя, то для него, на наш взгляд, вообще не представляется возможным проверить наличие технической возможности у суда.

Анализ судебной практики показывает, что, например, в арбитражном судопроизводстве, суды трактуют основание «отсутствие технической возможности у суда» для отказа в применении ВКС не как то, что суды не оборудованы системой ВКС, а что в указанное стороной в ходатайстве время не представляется возможным провести сеанс видеоконференции (к примеру, занят оборудованный ВКС зал) [6]. На наш взгляд, данную причину нельзя признать уважительной.

Кроме указанного, на практике суды нередко сталкиваются с ситуацией, при которой отсутствие технической возможности видеоконференц-связи выявлено перед началом судебного заседания или в ходе его проведения (например, когда связь прервалась). В понимании того, следует ли суду отложить судебное разбирательство, либо суд вправе продолжить судебное заседание без участия отсутствующей стороны, позиции судов расходятся.

С одной стороны, одновременно с введением порядка судебного разбирательства с использованием системы видеоконференц-связи Федеральным законом от 26 апреля 2013 г. № 66-Ф3 были внесены изменения в ст. 169 ГПК РФ. Часть первая этой статьи дополнена новым основанием для вынесения судом определения об отложении разбирательства по делу - возникновение технических неполадок при использовании технических средств ведения судебного заседания, в том числе систем ВКС. С другой стороны, неполадки в системе ВКС являются свидетельством отсутствия технических условий использования этого средства связи в данном судебном заседании. Видимо, этот вопрос должен разрешаться судами с учетом возможности устранения технических проблем к следующему судебному заседа- 
нию, срока судебного разбирательства, характера дела и объективной необходимости заслушивания объяснений ходатайствующего о применении ВКС лица.

Стоит отметить высказывание А. Лейба по поводу того, что судья не должен обязательно обладать необходимыми знаниями в технической области, потому при использовании систем ВКС необходимо участие специалиста, который будет отвечать за проведение сеанса BKC [7]. Аналогичной точки зрения придерживается и А.А. Ярков [8].

Отсюда возникают противоречия, связанные с тем, как и кому следует определить, в каком случае наличие технических неполадок влечет за собой отсутствие у суда технической возможности. Например, когда во время сеанса ВКС изначально синхронизация картинки и звука была нормальной, а затем один из элементов исчез, либо во время сеанса наблюдаются искажения звука и изображения. Несомненно, данная неполадка будет существенным препятствием в дальнейшем рассмотрении дела.

Как утверждает А.А.Ярков факт наличия проблемы ухудшения качества связи оценивается весьма субъективно. При этом, ни судья, ни лицо, ответственное за техническое обеспечение проведения видеоконференц-связи, не в состоянии объективно принять решение о возможности либо невозможности дальнейшего проведения судебного заседания путем использования систем видеоконференц-связи при условии ухудшения качества связи. Решение проблемы А.А.Ярков видит в создании программно-технического комплекса, который на основе конкретных параметров сможет самостоятельно автоматически оценивать качество каждого сеанса видеоконференц-связи и доводить до сведения соответствующих лиц о наличии ухудшения качества связи и (или) отсутствия технической возможности проведения видеоконференц-связи вообще [8]. С этой позицией нельзя не согласиться, однако, на наш взгляд, данная тема скорее находится в технической, нежели правовой области и выходит за рамки гражданских процессуальных отношений, что, несомненно, не умаляет ее значимости, а возможно и служит основанием для проведения специального научно-технического исследования.

В случае обнаружения технических неполадок по общему правилу, установленному ч. 1 ст. 169 ГПК РФ, суд откладывает судебное разбирательство. Однако, как мы уже упоминали ранее, ГПК РФ так и не содержит разъяснения, что понимать под отсутствием технической возможности суда в организации ВКС: отсутствие оборудования для видеоконференций в суде, искажения звука или изображения или исчезновение одного из указанных элементов.
Тем не менее, с учетом отсутствия понятия «техническая возможность суда...», считаем необходимым сформулировать собственное авторское определение, где под технической возможностью суда в проведении видеоконференц-связи понимается наличие в суде системы видеоконференц-связи, применяемой для трансляции судебного заседания при условии такого качества изображения и звука, которые позволяли бы непосредственное непрерывное восприятие судом полученной информации, а также занесению ее в протокол судебного заседания в режиме реального времени.

С точки зрения реализации принципа социальной справедливости следует также отметить, что сегодня в гражданском процессуальном праве отсутствует должное правовое закрепление возможности отвода судей, организующих видеоконференц-связь по поручению суда, рассматривающего дело по существу.

Несомненно, на практике может сложиться ситуация, что судья, организующий судебное заседание, может оказать давление на лицо, дающее показания или объяснения посредством ВКС. Однако, отсутствие положения о возможности отвода судей может привести к нарушению единообразия его понимания на практике.

Так, в одном суде заявление об отводе судей, организующих проведение процессуальных действий посредством ВКС будут рассматриваться судами и удовлетворяться, а в других не приниматься и не рассматриваться. С одной стороны, данное положение отражает практическую реализацию принципа независимости судей, однако, с другой стороны, подобная ситуация может привести к нарушению принципа социальной справедливости.

Таким образом, неопределённость процессуального закона в части возможности заявления отвода таким судьям, а равно запрет на заявление и разрешение такого отвода, порождает объективные сомнения в беспристрастности суда, допускающего в производство по делу лиц, как подлежащих отводу, так и уже отведённых от участия в процессе. Производство по делу с таким составом участников не обеспечит устранение сомнений в достоверности полученных доказательств и соблюдение судьей опроса участников в атмосфере, исключающей возможность давления, а равно допрос в условиях, исключающих возможность общения допрошенных лиц с недопрошенными и другие ситуации.

Судьи, являющиеся заинтересованными лицами, на наш взгляд, подлежат обязательному отводу. При этом, как справедливо отмечает Р.В.Колпаков, суще- 
ствует определенный порядок отвода для всех лиц, которым он может быть заявлен, однако зачастую данный механизм отвода неэффективен, поскольку, например, отводимый судья сам рассматривает заявленный ему отвод $[9,10]$.

Отсюда следует сделать вывод о том, что заявление об отводе судьи, организующего судебное заседание посредством систем видеоконференц-связи, должно рассматриваться судьей, разрешающим дело по существу.

Опираясь на проведенное исследование, представляется необходимым предложить внести изменения в ст. 16 ГПК РФ, дополнив ее ч. 4 и изложив в следующей редакции «При наличии оснований, предусмотренных ч. 1 настоящей статьи, подлежат отводу судьи, выполняющие поручение об организации судебного заседания посредством видеоконференц-связи. При этом, заявление об отводе подается в суд, рассматривающий дело по существу».
На основании вышесказанного, отметим, что принцип социальной справедливости в контексте его реализации посредством систем ВКС в гражданском судопроизводстве затрагивает вопросы целесообразности отклонения ходатайств о проведении судебного заседания при использовании систем видеоконференц-связи на основании отсутствия технической возможности, когда одно лицо в подобном ходатайстве удовлетворяется, а другое, в силу неопределенности процессуального законодательства в трактовке понятия «техническая возможность», вынуждено претерпевать негативные последствия отказа в удовлетворении аналогичного ходатайства. Кроме того, на наш взгляд, социальная справедливость как общеправовой принцип затрагивает и проблему отвода суда, обеспечивающего проведение сеанса ВКС по поручению суда, рассматривающего дело по существу. Несомненно, высказанные нами предложения по устранению пробелов в законодательстве в указанных выше вопросах, будут служить и положительной практике реализации принципа социальной справедливости в процессе применения систем ВКС.

\section{ЛИТЕРАТУРА}

1. Федоренко Д.В. Общее и особенное во взаимодействии норм права и нравственности в условиях гражданского общества и правового государства // Адвокатская практика. 2006. № 4. С. 2.

2. Вайпан В.А. Теория справедливости: право и экономика: Монография. М., 2017. С. 345.

3. Вайпан В.А. Принцип социальной справедливости в судебной практике // Закон. 2018. № 3. С. 34.

4. Романова Ю.А. Некоторые вопросы правовой регламентации судебного заседания арбитражного суда с использованием систем видеоконференц-связи // Вестник Томского государственного университета. Право. 2013. № 1 (7).

5. Дело № СИП-727/2017 суда Санкт-Петербурга и Ленинградской области.

6. Определение Суда по интеллектуальным правам от 15.07.2019 по делу № СИП-460/2019 «06 отказе в удовлетворении ходатайства об участии в судебном заседании путем использования систем видеоконференц-связи» // Доступ из СПС «КонсультантПлюс».

7. Лейба А. Видеоконференцсвязь: недостатки и неполадки // ЭЖ-Юрист. 2013. № 27. С.7.

8. Ярков А.А. Ухудшение качества связи при использовании систем видеоконференц-связи // Арбитражный и гражданский процесс. № 10. 2018. С. 16.

9. Колпаков Р.В. Институт отвода в гражданском процессе Российской Федерации. Автореферат диссертации на соискание ученой степени кандидата юридических наук. Саратов. 2013. С. 3.

10. Колпаков Р.В. К вопросу об отводах судей в гражданском процессуальном законодательстве России // Закон и право. № 9. 2009. С. 42.

(с) Грунина Вероника Александровна ( vgrunvgrun@rambler.ru ),

Новичкова Юлия Геннадьевна ( 3590568@mail.ru ), Миронова Юлия Владимировна ( Juliamironova07@mail.ru ).

Журнал «Современная наука: актуальные проблемы теории и практики» 